\title{
PERNIKAHAN POLIGAMI \\ DI WILAYAH ADMINISTRASI KANTOR URUSAN AGAMA KECAMATAN PLAYEN TAHUN 2012-2015
}

\author{
Asmorohadi \\ Kantor Kementerian Agama Kabupaten Gunung Kidul \\ Mahasiswa Program Studi Magister Studi Islam \\ Universitas Muhammadiyah Yogyakarta
}

\begin{abstract}
The Office of Religious Affairs (KUA) of Playen District in Gunungkidul Regency has conducted polygamous marriages from 20122015 with the permission of the Religious Courts. From there it can be identified the reasons for polygamy and judges' consideration in it to find out the growing marital conditions in the region. This qualitative research method of data collection was carried out with documentation of various marriage documents and interviews with KUA Playen District, Gunungkidul Regency
\end{abstract}

Keywords: polygamous marriages, Office of Religious Affairs, reasons

Abstrak: KUA Kecamatan Playen Kabupaten Gunungkidul telah melaksanakan pernikahan poligami dari tahun 2012-2015 atas izin Peradilan Agama. Dari situ dapat diidentifikasi alasan poligami dan pertimbangan hakim di dalamnya untuk mengetahui kondisi perkawinan yang berkembang di wilayah tersebut. Penelitian kualititatif dengan instrument dokumentasi dan wawancara terhadap pegawai KUA Kecamatan Playen Kabupaten Gunungkidul adalah alat pengumpul data penelitiannya.

Kata kunci: perkawinan poligami, Kantor Urusan Agama, alasan

\section{A. Pendahuluan}

Kholis telah menegaskan arti penting keluarga di dalam al-Qur`an. Di dalamnya ada hukum keluarga sebanyak 70 ayat. Di samping itu, institusi keluarga merupakan lembaga terkecil dari masyarakat, baik lakilaki ataupun perempuan merupakan entitas penting dalam keluarga. ${ }^{1}$ Meski demikian, ayatnya juga tidak melarang poligami, tetapi juga tidak membiarkannya tanpa aturan. Ajarannya telah mengatur dengan syarat-

1 Muhammad Nur Kholis, "Konsep Kepala Keluarga Antara Laki-Laki Dan Perempuan Dalam Surat An Nisa (4) Ayat 34," Istinbath Jurnal Hukum Vol 12 No 2 (2015), h. 274-290 
syarat imaniyah, bahkan membatasi poligami hanya sampai empat orang. ${ }^{2}$ Jadi, Islam membolehkan laki-laki beristri lebih dari satu wanita asalkan dapat berlaku adil. Yang menjadi persoalan adalah pada persyaratan adil ini, terutama dalam hal membagi cinta. Tujuan ideal Islam dalam perkawinan adalah monogami.

Karena itu, dalam hokum perkawinan Islam Indonesia, Poligami memiliki kesetaraan dengan pernikahan usia dini dari sisi keterbatasan pelaksanaannya. Pernikahan usia dini perlu dihindari sehingga harus ada izin dari PA agar dapat dilaksanakan oleh aparat KUA. ${ }^{3}$

Keduanya harus memiliki izin PA Di Indonesia, perkawinan poligami telah di atur dalam Undang-undang No.1 tahun 1974 dalam Pasal 3 memuat beberapa ketentuan sebagai berikut : ${ }^{4}$

1. Pada dasarnya dalam suatu perkawinan, seseorang hanya mempunyai seorang istri, wanita hanya boleh mempunyai seorang suami.

2. Pengadilan dapat memberikan izin kepada seorang suami untuk beristri lebih dari seorang apabila dikehendaki oleh pihak-pihak yang bersangkutan.

Selanjutnya, Hukum Perkawinan memberi batasan mengenai pengecualian itu, yaitu berupa suatu pemenuhan syarat disertai dengan alasan yang dapat diterima serta harus mendapat izin dari pengadilan. Hal ini sebagaimana yang tertuang dalam Undang-Undang Perkawinan pasal 3 ayat 2 yang berbunyi: pengadilan dapat memberi izin kepada seorang suami untuk beristri lebih dari seorang apabila dikehendaki oleh pihakpihak yang bersangkutan. ${ }^{5}$

Dalam pasal 4 ayat 2 Undang-Undang No. 1 Tahun 1974 tentang Perkawinan, juga dijelaskan bahwa pengadilan hanya memberikan izin pada suami yang akan beristri lebih dari seorang apabila:

2 Abu Salma Al Atsari, Poligami Dihujat Jawaban : Rasional Bagi Para Penghujat Syariat dan Sunnah Poligami, dear.to/abusalma, 2007, h. 14

3 Andrie Irawan, "Harmonisasi Hukum Nasional dan Hukum Islam dalam Mencari Batasan Usia Minimal Menikah bagi Anak,” Jurnal Hukum Respublica, Vol. 10, No. 2, 2011, h. 247-26o

4 Muhammad Saleh Ridwan, "Poligami Dalam Perundang-Undangan Perkawinan di Indonesia”, Al-Risalah : Volume 10 Nomor 2 Nopember 2010.

5 Undang-undang Nomor 1 Tahun 1974 Pasal 3 ayat 2 
a. Istri tidak dapat menjalankan kewajibannya sebagai istri.

b. Istri mendapat cacat badan atau penyakit yang tidak dapat disembuhkan.

c. Istri tidak dapat melahirkan keturunan.

Untuk dapat mengajukan permohonan pada pengadilan harus dipenuhi syarat-syarat yang tertuang dalam pasal 5 ayat 1 , yaitu sebagai berikut:

a. Adanya persetujuan dari istri atau istri-istri

b. Adanya kepastian bahwa suami mampu menjamin keperluankeperluan hidup istri-istri dan anak-anak mereka.

c. Adanya jaminan bahwa suami akan beerlaku adil terhadap istri-istri dan anak-anak mereka

Poligami boleh dilaksanakan dengan persyaratan-persyaratan tertentu, demikian juga permohonan izin poligami harus diajukan melalui sidang pengadilan. Hal ini dilakukan karena poligami bukan sesuatu yang mudah dan gampang. Karena dalam sebuah perkawinan terdapat masalah-masalah yang komplek, tidak hanya menyangkut hubungan suami isteri saja namun juga berhubungan dengan keluarga dari kedua belah pihak serta anak-anak hasil dari perkawinan mereka.

Meski demikian proses administrasi dan pencatatan pernikahan poligami tidak bisa terlepas dari Kantor Urusan Agama (KUA). Kantor ini berperan memberikan penguat dan rekomendasi bagi permohonan izin poligami ke pengadilan agama (PA). Apabila izin telah disahkan melalui PA, KUA wajib melaksanakan dengan melakukan pencatatan pernikahan tersebut. Maka, KUA sebagai pihak yang menerima, memeriksa dan mencatat peristiwa pernikahan poligami. Demikian pula Pengadilan Agama yang memberikan izin atau tidak dengan melihat alasan-alasan yang diajukan dan terpenuhi atau tidaknya persyaratan-persyaratan poligami baik secara hukum Islam maupun undang-undang.

KUA Kecamatan Playen Kabupaten Gunungkidul layak diteliti dalam perkara poligami. dari tahun 2012-2015 telah tercatat empat peristiwa pernikahan poligami. Dari situ dapat diidentifikasi alasan poligami dan dasar hukumnya didalamnya termasuk pelaksanaannya. 
Penelitian kualititatif dengan informan utama adalah pegawai KUA Kecamatan Playen Kabupaten Gunungkidul.

\section{B. Deskripsi Perkara Pernikahan Poligami}

Dari tahun 2012 sampai dengan tahun 2015, jumlah pernikahan di Kantor Urusan Agama Kecamatan Playen sebanyak 1.905 peristiwa. Dari 1.905 peristiwa pernikahan 4 diantaranya adalah pernikahan poligami, dengan perincian sebagai berikut :

\begin{tabular}{|c|c|c|c|c|c|c|c|c|c|}
\hline \multirow{3}{*}{ No } & \multirow{3}{*}{$\begin{array}{c}\text { Tahu } \\
\mathrm{n}\end{array}$} & \multicolumn{8}{|c|}{ Nikah } \\
\hline & & \multicolumn{2}{|c|}{ Wali } & \multirow{2}{*}{$\mathrm{Jml}$} & \multirow{2}{*}{$\begin{array}{l}\text { Camp } \\
\text { uran }\end{array}$} & \multicolumn{3}{|c|}{ Poligami } & \multirow{2}{*}{$\begin{array}{l}\text { Bawah } \\
\text { Umur }\end{array}$} \\
\hline & & Nasab & Hakim & & & II & III & IV & \\
\hline 1. & 2012 & 496 & 33 & 529 & - & 1 & - & - & 6 \\
\hline 2. & 2013 & 435 & 44 & 479 & - & 1 & - & - & 9 \\
\hline 3. & 2014 & 420 & 26 & 446 & - & - & - & - & 6 \\
\hline 4. & 2015 & 418 & 33 & 451 & - & 2 & - & - & 11 \\
\hline \multicolumn{2}{|c|}{ Jumlah } & 1.769 & 136 & 1.905 & - & 4 & - & - & 32 \\
\hline
\end{tabular}

Dari tabel diatas, dapat kita ketahui bahwa prosentase pernikahan poligami di KUA Kecamatan Playen Kabupaten Gunungkidul relatif kecil yakni 0,20\%. Semuanya adalah pernikahan poligami kedua.

Dari pernikahan poligami yang ada di KUA Playen, alasan yang diajukan suami bervariatif. Diantaranya : suami ingin menambah keturunan karena isteri sudah tidak bisa memberikan keturunan lagi, istri sering mengalami sakit ketika melakukan hubungan suami istri (kulit sensitif), Istri tidak dapat menjalankan kewajiban sebagai seorang istri dan Isteri tidak dapat memberikan keturunan. Adapun perinciannya sebagai berikut :

\begin{tabular}{|l|l|l|c|l|}
\hline No & No Putusan & Alasan & $\begin{array}{c}\text { Tanggal } \\
\text { Nikah }\end{array}$ & $\begin{array}{l}\text { Nomor Akta } \\
\text { Nikah }\end{array}$ \\
\hline & & $\begin{array}{l}\text { Suami ingin } \\
\text { menambah } \\
\text { keturunan karena } \\
\text { isteri sudah tidak } \\
\text { bisa memberikan } \\
\text { keturunan lagi }\end{array}$ & $\begin{array}{l}\text { 0908/Pdt.G/2-2012 } \\
\text { 012/Pa.Wno }\end{array}$ & $\begin{array}{l}\text { 0489/053/XI } \\
/ 2012\end{array}$ \\
\hline 2. & 0135/Pdt.G/20 & Istri sering & 01-06-2013 & 0174/o08/VI \\
\hline
\end{tabular}




\begin{tabular}{|l|l|l|l|l|}
\hline & 13/PA.Yk & $\begin{array}{l}\text { mengalami sakit } \\
\text { ketika melakukan } \\
\text { hubungan suami } \\
\text { istri (kulit sensitif) }\end{array}$ & & $/ 2013$ \\
\hline 3. & $\begin{array}{l}\text { 0240/Pgt.G/2 } \\
\text { 015/PA.Wno }\end{array}$ & $\begin{array}{l}\text { Istri tidak dapat } \\
\text { menjalankan } \\
\text { kewajiban sebagai } \\
\text { seorang istri }\end{array}$ & 15-05-2015 & $\begin{array}{l}\text { 0143/025/V/ } \\
2015\end{array}$ \\
\hline 4. & $\begin{array}{l}\text { 0410/Pdt.G/2 } \\
\text { 015/PA.Mkd }\end{array}$ & $\begin{array}{l}\text { Isteri tidak dapat } \\
\text { memberikan } \\
\text { keturunan }\end{array}$ & 26-07-2015 & $\begin{array}{l}\text { 0205/O30/VI } \\
\text { I/2015 }\end{array}$ \\
\hline
\end{tabular}

\section{Alasan-alasan Permohonan Izin Pernikahan Poligami}

Dari perkara-perkara tersebut penyusun akan mendeskripsikan 4 (empat) putusan sesuai dengan alasan-alasan suami melakukan pernikahan poligami, sedangkan perinciannya sebagai berikut :

1. Perkara Nomor 0908/Pdt.G/2012/Pa.Wno.

Perkara ini didaftarkan di kepaniteraan PA Wonosari pada tanggal 23 Agustus 2012 dan telah diputus pada tanggal 15 Oktober 2012 dengan putusan mengabulkan permohonan pemohon yaitu izin melakukan pernikahan poligami. Adapun perinciannya adalah:

a. Pemohon berusia 37 tahun, agama Islam, pekerjaan Petani, Tempat Tinggal di Dusun Sawahan II RT. 040 RW. oo6 Bleberan, Playen, Gunungkidul.

b. Termohon berumur 34 tahun, agama Islam, pekerjaan Petani, Tempat Tinggal di Dusun Sawahan II RT. 040 RW. oo6 Bleberan, Playen, Gunungkidul.

c. Calon Isteri Kedua Pemohon berumur 35 tahun, agama Islam, pekerjaan Petani, Tempat Tinggal di RT. 035 RW. 007 Bleberan, Playen, Gunungkidul.

Pemohon menikah dengan Termohon pada tanggal 29 Agustus 2005 dan sudah berhubungan layaknya suami isteri. Sampai saat ini Termohon hanya memberikan seorang keturunan, padahal Pemohon ingin mempunyai keturunan lagi. Tetapi Termohon tidak dapat lagi melahirkan keturunan, sebab menurut keterangan dokter ada kelainan yakni lemah 
jantung. Termohon menyatakan rela dan tidak keberatan apabila Pemohon menikah lagi dengan calon isteri kedua Pemohon. ${ }^{6}$

2. Perkara Nomor 0135/Pdt.G/2013/PA.Yk.

Perkara ini didaftarkan di kepaniteraan PA Yogyakarta pada tanggal 11 Maret 2013 dan telah diputus pada tanggal 18 April 2013 dengan putusan mengabulkan permohonan pemohon yaitu izin melakukan pernikahan poligami. Adapun perinciannya adalah :

a. Pemohon berumur 35 tahun, agama Islam, Pekerjaan Wiraswasta, Tempat Tinggal di Jl. Purbayan No. 18 RT. 49 RW. 11 Purbayan, Kotagede, Yogyakarta.

b. Termohon berumur 29 tahun, agama Islam, Pekerjaan Ibu Rumah Tangga, Tempat Tinggal di Jl. Purbayan No. 18 RT. 49 RW. 11 Purbayan, Kotagede, Yogyakarta.

c. Calon Isteri Kedua Pemohon berumur 21 tahun, agama Islam, Tempat Tinggal Dusun Gading 2, Gading, Playen, Gunungkidul.

Pemohon telah menikah dengan Termohon pada tanggal o1 April 1999 dan telah dikaruniai 1 orang anak. Pemohon mengajukan permohonan izin pernikahan poligami karena dalam perjalananan rumah tangganya setiap melakukan hubungan suami istri, Termohon sering mengalami sakit (kulit sensitif) dan Pemohon sangat khawatir akan melakukan perbuatan yang dilarang oleh norma Agama apabila Pemohon tidak melakukan poligami. Dengan penyakit yang diderita, Termohon tidak dapat melaksanakan kewajiban sebagai isteri dengan baik dan sempurna. Pemohon telah memusyawarahkan rencananya untuk menikah lagi kepada Termohon dan keluarga. Pemohon melaksanakan poligami dengan niat yang baik dan berjanji akan berlaku adil terhadap isteri-isteri Pemohon dan tidak akan menyia-nyiakan Termohon. Begitu juga calon isteri kedua Pemohon sudah menyatakan siap untuk menjadi isteri kedua Pemohon. ${ }^{7}$

3. Perkara Nomor 0240/Pgt.G/2015/PA.Wno.

${ }^{6}$ Salinan Putusan PA Wonosari Nomor 0908/Pdt.G/2012/Pa.Wno

7Salinan Putusan PA Yogyakarta Nomor 0135/Pdt.G/2013/PA.Yk. 
Perkara ini didaftarkan di kepaniteraan PA Wonosari pada tanggal 24 Februari 2015 dan telah diputus pada tanggal 22 April 2015 dengan putusan mengabulkan permohonan pemohon yaitu izin melakukan pernikahan poligami. Adapun perinciannya adalah :

a. Pemohon berumur 42 tahun, agama Islam,Pekerjaan Buruh Harian Lepas, Tempat Tinggal di Ngepung RT. o9 RW. 03. Bunder, Patuk, Gunungkidul.

b. Termohon berumur 41 tahun, agama Islam, Pekerjaan Mengurus Rumah Tangga, Tempat Tinggal di Dusun Ngepung RT. o9 RW. 03. Bunder, Patuk, Gunungkidul.

c. Calon Isteri Kedua Pemohon berumur 31 tahun, agama Islam, Tempat Tinggal Dusun Banaran V RT.028 RW. 005, Banaran, Playen, Gunungkidul.

Pemohon telah menikah dengan Termohon pada tanggal 12 Mei 1995 dan telah dikaruniai 3 orang anak yang sekarang. Pemohon mengajukan permohonan izin pernikahan poligami karena Pemohon ingin mempunyai anak lagi tetapi Termohon tidak mau melayani (Termohon tidak dapat menjalankan kewajiban sebagai seorang istri) dan Pemohon ingin membentuk keluarga Muslim serta sangat khawatir akan melakukan perbuatan yang dilarang oleh norma Agama apabila tidak melakukan pernikahan poligami. 8

4. Perkara Nomor 0410/Pdt.G/2015/PA.Mkd.

Perkara ini didaftarkan di kepaniteraan PA Mungkid padatanggal 23 Februari 2015 dan telah diputus pada tanggal 12 Mei 2015 dengan putusan mengabulkan permohonan pemohon yaitu izin melakukan pernikahan poligami.Adapun perinciannya adalah :

a. Pemohon berumur 48 tahun, agama Islam, pekerjaan Karyawan swasata berdomisili di di Dusun Soka RT. 03 RW. 01 Mertoyudan, Mertoyudan, Magelang.

${ }^{8}$ Salinan Putusan PA Wonosari Nomor 0240/Pgt.G/2015/PA.Wno. 
b. Termohon berumur 51 tahun,agama Islam, pekerjaan Mengurus Rumah Tangga, Tempat Tinggal di Dusun Soka RT. o3 RW. 01 Mertoyudan, Mertoyudan, Magelang.

c. Calon Isteri Pemohon berusia 35 tahun, agama Islam, Tempat Tinggal Dusun Gembuk RT. 029 RW. 05 Getas, Playen, Gunungkidul.

Pemohon mengajukan permohonan izin pernikahan poligami dengan alasan bahwa isterinya (Termohon) tidak dapat memberikan keturunan kepada Pemohon kemudian menyuruh Pemohon menikah lagi dengan calon istri kedua. 9

\section{Dasar Sosiologis dan Yuridis dalam Izin Poligami}

Dasar hukum yang digunakan dalam setiap putusan berisi tentang dasar hukum hakim dalam memutuskan perkara. Karena PA adalah Pengadilan Islam Indonesia, maka dasar hukum putusannya adalah segalaperaturan perundang-undangan negara yang berlaku dan relevan, disusun menurut hirarkinya / urutan derajatnya dan urutan tahun terbitnya kemudian berdasarkan hukum Islam atau hukum yang tidak tertulis lainnya.

Dalam sebuah putusan bagian pertimbangan adalah bagian yang dimulai dengan "Tentang Pertimbangan Hukumnya atau Tentang Hukumnya" yang memuat :

1. Gambaran tentang bagaimana hakim mengkualifisir, yaitu mencari dan menemukan hukum yang harus diterapkan pada suatu fakta dan kejadianyang diajukan.

2. Penilaian Hakim tentang fakta-fakta yang diajukan.

3. Pertimbangan Hakim secara kronologis dan rinci setiap item, baik dari pihak penggugat maupun tergugat.

4. Dasar hukum yang digunakan hakim dalam menilai fakta dan memutus perkara, hukum tertulis maupun hukum tidak tertulis.

Selanjutnya penyusun akan mengemukakan dasar hukum dan pertimbangan hakim dalam putusan-putusan yang telah penyusun sebutkan diatas :

${ }_{9}$ Salinan Putusan PA Mungkid Nomor 0410/Pdt.G/2015/PA.Mkd. 
1. Perkara Nomor 0908/Pdt.G/2012/Pa.Wno

Dengan alasan di atas hakim mengabulkan permohonan Pemohon untukmelakukan pernikahan poligami. Pertimbangan hukum yang digunakan adalah :

a. Menimbang, bahwa Majelis Hakim sudah berusaha mendamaikan dan menasehati Pemohon agar memikirkan kembali niatnya untuk menikah lagi / poligami, dan kepada Termohon agar memikirkan akibat dari Pemohon mempunyai istri lebih dari seorang, Pemohon tetap pada pendiriannya untuk melanjutkan permohonannya sedangkan Termohon tidak keberatan.

b. Menimbang, bahwa untuk memenuhi Peraturan Mahkamah Agung Nomor 1 Tahun 2008 terhadap perkara ini telah dilakukan proses mediasi, namun berdasarkan laporan mediator mediasi dinyatakan tidak berhasil / gagal.

c. Menimbang, bahwa Pemohon mengajukan permohonan izin untuk menikah lagi dengan alasan karena Termohon menderita penyakit jantung sehingga tidak dapat melayani hubungan badan secara maksimal dan tidak dapat melahirkan keturunan lagi sedangkan Pemohon masih sangat menginginkan anak.

d. Menimbang, bahwa dari jawaban Termohon terbukti Termohon mengetahui Pemohon akan menikah lagi dan Termohon benar-benar merelakannya karena Termohon menyadari kekurangannya dengan penyakit jantung yang dideritanya sehingga tidak dapat melahirkan anak lagi.

e. Menimbang, bahwa berdasarkan bukti P 8 tertera peenghasilan Pemohon sebesar Rp. 1.500.000,- (satu juta lima ratus ribu rupiah) per bulan dan hal tersebut dibenarkan oleh Termohon, maka bukti tersebut sebagai pendukung persyaratan sebagaimana dimaksudkan Pasal 5 ayat (1) huruf (b) Undang-undang Nomor 1 Tahun 1974 dapat terpenuhi oleh Pemohon.

f. Menimbang, bahwa berdasarkan bukti P 6 dan dipertegas secara lisan dalam persidangan yang pada pokoknya bahwa Pemohon sanggup berlaku adil terhadap istri-istrinya, maka bukti tersebut sebagai 
pendukung persyaratan sebagaimana dimaksudkan Pasal 5 ayat (1) huruf (c) Undang-undang Nomor 1 Tahun 1974.

g. Menimbang, bahwa alat-alat bukti tertulis $\mathrm{P} 1$ hungga $\mathrm{P} 10$ serta $\mathrm{P} 12$ kesemuanya telah memenuhi kriteria sebagai alat bukti tertulis dan Termohon menerimanya sehingga dinyatakan dapat diterima.

h. Menimbang, bahwa dipersidangan telah didengar keterangan dua orang saksi, kesemuanya membenarkan adanya kehendak dari Pemohon untuk menikah lagi karena Pemohon telah menjalin hubungan dengan Mawar binti Rebo, dan telah dilakukan pelamaran. Kehendak menikah lagi tersebut telah disetujui oleh Termohon karena saksi-saksi mendengar sendiri kerelaan tersebut dari Termohon, kedua saksi menjamin bahwa Pemohon mampu berlaku adil terhadap istriistrinya karena secara materi Pemohon mamapu berpenghasilan cukup untuk memenuhi kebutuhan hidup istri-istrinya dan berperilaku baik dengan kondisi rumah tangga yang selalu rukun bersama Termohon.

i. Menimbang, bahwa berdasarkan persyaratan izin perpoligami sebagaimana yang tercantum dalam Undang-undang Nomor 1 Tahun 1974 Pasal 4 dan 5, seseorang yang akan melakukan poligami harus memenuhi persyaratan pada Pasal 4 yang merupakan syarat alternatif serta Pasal 5 yang merupakan persyaratan komulatif.

j. Menimbang, bahwa dipersidangan ditemukan fakta yang mendukung terpenuhinya syarat alternatif sebagaimana tercantum pada pasal 4 dan fakta yang mendukung terpenuhinya syarat komulatif oleh Pemohon.

k. Menimbang, bahwa secara normatif harus dipertimbangkan segi kemaslahatan hidup Pemohon dan Termohon dalam bermasyarakat, Pemohon yang telah begitu kuatnya untuk menikah lagi dengan alasan Termohon tidak dapat melahirkan lagi sedangkan Pemohon masih menginginkan anak, fakta ini harus dipertimbangkan dan jika kehendak Pemohon tersebut tidak dikabulkan oleh lembaga peradilan, sementara terdapat fakta Termohon sebagai istri telah benar-benar mengizinkan, Pemohon berpenghasilan cukup, serta tidak ada kekhawatiran dari Termohon selaku istri pertama Pemohon 


\section{Pernikahan Poligami Di Wilayah Administrasi}

KUA Kecamatan Playen Tahun 2012-2015

bahwasanya jika diizinkan untuk berpoligami Pemohon dimasa yang akan datang akan berbuat aniaya/tidak adil terhadap dirinya, akan menjamur yang disebut sebagai nikah sirri ditengah-tengah masyarakat yang tentunya akan menimbulkan kekacauan secara kependudukan maupun administrasi kenegaraan lainnya, maka fakta normatif tersebut patut dipertimbangkan dan bukan hanya mendasar pada fakta yuridis formal dalam syarat alternatif yang tercantum dalam Pasal 4 Undang-undang Nomor 1 Tahun 1974.

1. Menimbang, bahwa Hakim perlu mengetengahkan firman Allah dalam QS. an-Nisa ayat 3 yang berbunyi :

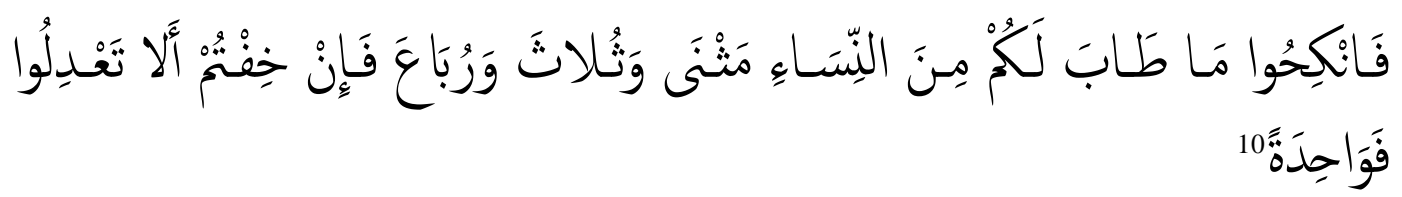

2. Perkara Nomor 0135/Pdt.G/2013/PA.Yk.

Dengan alasan di atas hakim mengabulkan permohonan untuk melakukan pernikahan poligami. Pertimbangan hukum yang digunakan adalah :

a. Menimbang, bahwa dalam perkara a quo Majelis Hakim telah berupaya mendamaikan Pemohon dan Termohon melalui proses mediasi sesuai dengan Peraturan Mahkamah Agung Nomor 1 Tahun 2008 Tentang Proses Mediasi di PA dengan seorang Mediator namun ternyata upaya perdamaian melalui proses mediasi tidak berhasil.

b. Menimbang, bahwa meskipun upaya perdamaian melalui proses mediasi tidak berhasil mencapai kesepakatan untuk damai, Majelis Hakim tetap berupaya mendamaikan Pemohon dan Termohon di setiap tahapan persidangan agar Pemohon mencukupkan dengan beristrikan Termohon sesuai ketentuan Pasal 130 ayat (1) HIR, namun upaya perdamaian tersebut tidak berhasil sampai putusan ini dijatuhkan.

c. Menimbang, bahwa yang menjadi alasan pokok Pemohon mengajukan permohonan izin poligami ini adalah karena di setiap melakukan

${ }^{10}$ Salinan Putusan PA Wonosari Nomor 0908/Pdt.G/2012/Pa.Wno 
hubungan suami istri, Termohon sering mengalami sakit karena kulit sensitif.

d. Menimbang bahwa dalam persidangan Termohon mengajukan jawaban secara lisan yang pada intinya secara tegas mengakui dan membenarkan semua dalil permohonan Pemohon dan Termohon menyatakan ia tidak keberatan atas keinginan Pemohon untuk beristri lagi (poligami).

e. Menimbang, bahwa oleh karena Termohon telah memberikan pengakuan atas kebenaran dalil yang diajukan oleh Pemohon, dimana pengakuan merupakan alat bukti yang sempurna dan mengikat maka dengan demikian dalil permohonan Pemohon telah terbukti secara sah namun sesuai ketentuan Pasal 41 dan Pasal 42 ayat (1) Peraturan Pemerintah Nomor 9 Tahun 1975 tentang Pelaksanaan Undangundang Nomor 1 Tahun 1974 tentang Perkawinan jo Pasal 57 dan 58 Kompilasi Hukum Islam, Majelis Hakim harus memeriksa : 1) ada tidaknya alasan yang memungkinkan Pemohon kawinlagi, 2) ada tidaknya persetujuan dari istri baik lisan maupun tertulis, 3) ada tidaknya kemampuan Pemohon menjamin keperluan hidup istri-istri dan anak-anaknya, 4) ada tidaknya jaminan Pemohon akan berlaku adil terhadap istri-istri dan anak-anaknya, dan 5) PA harus memanggil dan mendengan istri Pemohon (Termohon)

f. Menimbang, bahwa untuk memperkuat dalil permohonannya, Pemohon telah mengajukan alat bukti surat berupa : Foto Copy Kutipan Akta Nikah (P 2), Foto Copy Kartu Tanda Penduduk atas nama Termohon (P 8) dan atas nama calon istri kedua Pemohon (P 9). Oleh karena itu sesuai ketentuan Pasal 165 HIR jo Pasal 1868 KUHPerdata.

g. Menimbang, bahwa selain alat bukti surat berupa foto copy diatas, Pemohon juga telah mengajukan alat bukti Asli Akta Sepihak berupa : Surat Pernyataan Tidak Keberatan Dimadu (P 3), Surat Pernyataan Bersedia Menjadi Istri Kedua (P 4), Surat Pernyataan Berlaku Adil (P 5), Surat Pernyataan Pendapatan (P 6) dan Surat Pernyataan Belum Pernah Menikah (P 7). Oleh karena itu Akta Sepihak diatas telah terbukti memenuhi syarat formil dan Materiil sebagai Akta Sepihak. 


\section{Pernikahan Poligami Di Wilayah Administrasi}

KUA Kecamatan Playen Tahun 2012-2015

h. Menimbang, bahwa disamping alat-alat bukti surat diatas ( $\mathrm{P}_{2}, \mathrm{P}_{3}, \mathrm{P}$ 4, P 5, P 6, P 7, P 8 dan P 9), Pemohon mengajukan alat bukti dua orang saksi di depan persidangan.

i. Menimbang, bahwa dua orang saksi yang diajukan oleh Pemohon telah menerangkan hal-hal yang diketahuinya sendiri secara terpisah dibawah sumpah, oleh karena itu berdasarkan Pasal 147 dan Pasal 171 ayat (1) HIR jo Pasal 1907 dan Pasal 1911 KUHPerdata kesaksian kedua saksi tersebut dapat dipertimbangkan lebih lanjut.

j. Menimbang, bahwa selain saksi-saksi tersebut diatas telah memenuhi syarat formil dan materiil sebagai saksi dan jumlahnya telah mencapai batas minimal pembuktian (vide. Pasal 169 HIR), juga ternyata keterangan saksi-saksi tersebut diatas saling bersesuaian antara yang satu dengan yang lain dan mendukung dalil permohonan Pemohon (vide. Pasal 172 HIR), dengan demikian kesaksian dua orang saksi diatas dapat diterima dan dapat dijadikan alat bukti serta menguatkan dalil permohonan Pemohon.

k. Menimbang, bahwa berdasarkan dalil permohonan Pemohon, keterangan saksi-saksi dan bukti-bukti lain yang telah dipertimbangkan tersebut diatas, Majelis Hakim dapat menemukan dan menyimpulkan fakta-fakta.

1. Menimbang, bahwa berdasarkan keterangan Pemohon yang dibenarkan oleh Termohon dan didukung oleh keterangan para saksi Pemohon serta dikuatkan dengan bukti-bukti Pemohon, maka Majelis Hakim berkesimpulan bahwa permohonan Pemohon untuk beristri lagi (berpoligami) telah terbukti dan memenuhi ketentuan Pasal 4 Undangundang Nomor 1 Tahun 1974 jo Pasal 57 Kompilasi Hukum Islam dan Pasal 5 Undang-undang Nomor 1 Tahun 1974 jo Pasal 58 Kompilasi Hukum Islam serta Pasal 41 Peraturan Pemerintah Nomor 9 Tahun 1975, maka permohonan Pemohon pada petitum point 2 dapat dikabulkan. ${ }^{11}$

3. Perkara Nomor 0240/Pdt.G/2015/PA.Wno.

${ }^{11}$ Salinan Putusan PA Yogyakarta Nomor 0135/Pdt.G/2013/PA.Yk. 
Dengan alasan di atas hakim mengabulkan permohonan Pemohon untuk melakukan pernikahan poligami. Pertimbangan hukum yang digunakan adalah :

a. Menimbang bahwa proses nasehat baik dari Majelis Hakim maupun Mediator telah ternyata tidak berhasil sebagaimana tercantum dalam Surat Keterangan Hakim Mediator.

b. Menimbang bahwa dalam persidangan Pemohon mengajukan poligami ini dengan alasan Termohon tidak bisa lagi melaksanakan kewajiban sebagai seorang istri.

c. Menimbang bahwa dalam persidangan Termohon hadir in person dan telah memberikan jawaban secara lisan yang pada inti pokoknya mengakui dalil-dalil permohonan Pemohon serta menyatakan tidak keberatan dengan permohonan Pemohon.

d. Menimbang bahwa dari hasil pemerikasaan di persidangan, Majelis menemukan fakta hukum yang pada inti pokoknya dapat disimpulkan sebagai berikut :

a. Bahwa Termohon telah ternyata mengakui dalil-dalil permohonan Pemohon.

b. Bahwa Termohon menyatakan bersedia dan rela dimadu serta mengizinkan Pemohon untuk menikah lagi (bukti P 11)

c. Bahwa calon istri Pemohon telah memasuki usia dewasa in casu janda cerai mati (bukti P 6)

d. Bahwa masing-masing saksi yang diajukan oleh Pemohon, telah ternyata menguatkan seluruh dalil permohonan Pemohon.

e. Menimbang, bahwa berdasarkan uraian fakta sebagaimana tersebut diatas, Majelis berpendapat, terdapat alasan dan fakta hukum yang cukup untuk menyatakan bahwa permohonan Pemohon telah beralasan hukum, memenuhi maksud dan ketentuan pasal 4 ayat (2) huruf (a) Undang-Undang Nomor 1 Tahun 1974 tentang Perkawinan jo Pasal 57 huruf (a) dan Pasal 58 Kompilasi Hukum Islam di Indonesia.

f. Menimbang bahwa selanjutnya, dengan bersandar pada prinsip hukum bahwa poligami merupakan situasi eksepsional dari asas monogami yang menjadi prinsip dasar dari Undang-undang Perkawinan, Majelis 
berpendapat bahwa pengabulan terhadap sebuah poligami sepenuhnya akan disandarkan pada pertimbangan yang mencakup tentang faktor kemampuan Pemohon dan tingkat kepentingan yang terkait dengan nilai-nilai dan unsur maslahat dan mafsadat sebagaimana terurai di bawah ini.

g. Menimbang bahwa dari fakta hukum sebagaimana telah dipertimbangkan di depan, In Casu Termohon menyatakan tidak keberatan dihubungkan dengan fakta bahwa Pemohon masih dalam usia produktif, in casu dorongan keinginan untuk melakukan hubungan suami istri dan keinginan untuk mempunyai anak lagi sebagai alasan dari al-mallaẓu-ash-shāhiyyah, telah ternyata masih cukup kuat, dorongan keinginan mana, meskipun secara faktual tidak dapat dibuktikan akan tetapi Majelis dengan bersandar pada pengetahuan umum bahwa dorongan keinginan yang terkait dengan almalladzu-assyahiyyah bagi seorang laki-laki dalam usia produktif sangatlah kuat, serta dengan pertimbangan bahwa hubungan Pemohon dengan calon istri kedua telah sedemikian eratnya, sehingga apabila Pemohon tidak diberi izin untuk menikah lagi, akan terjerumus pada dosa yang berkepanjangan serta dengan pertimbangan bahwa Pemohon mempunyai penghasilan yang cukup sebagaimana bukti P 8 dan sanggup berlaku adil sebagaimana P 9 serta Termohon telah menyatakan rela dimadu sebagaimana bukti P 11, Majelis berpendapat bahwa, terdapat alasan hukum yang cukup untuk memberi izin kepada Pemohon untuk melakukan poligami.12

4. PerkaraNomor 0410/Pdt.G/2015/PA.Mkd.

Dengan alasan di atas hakim mengabulkan permohonan Pemohon untuk melakukan pernikahan poligami. Pertimbangan hukum yang digunakan adalah :

a. Menimbang, bahwa dalam perkara ini Majelis Hakim telah memberi kesempatan kepada Pemohon dan Termohon untuk melaksanakan perdamaian melalui mediasi, yang didampingi mediator dari Hakim PA

12Salinan Putusan PA Wonosari Nomor 0240/Pgt.G/2015/PA.Wno. 
Mungkid. dalam perkara ini sesuai dengan Perma Nomor 1 Tahun 2008 namun gagal, maka Majelis Hakim kemudian melanjutkan pemeriksaan terhadap perkara ini.

b. Menimbang, bahwa berdasarkan bukti P 8 tidak keberatan dimadu, terbukti Termohon sebagai istri bersedia dimadu.

c. Menimbang, bahwa berdasarkan bukti $\mathrm{P} 7$ pernyataan berlaku adil, terbukti Pemohon sanggup berlaku adil terhadap istri-istri dan anaknya dikemudian hari.

d. Menimbang, bahwa berdasarkan permohonan Pemohon yang dibenarkan oleh Termohon tentang alasan Pemohon bahwa istri Pemohon tidak dapat melahirkan dan bersedia dimadu maka patut dianggap terbukti alasan tersebut, oleh karena itu telah terpenuhi Pasal 4 ayat (2) huruf (c) Undang-undang Nomor 1 Tahun 1974 tentang Perkawinan jo Pasal 41 huruf (a) point 3 Peraturan Pemerintah Nomor 9 Tahun 1975 tentang Pedoman Pelaksanaan Undang-undang Nomor 1 Tahun 1974 tentang Perkawinan jo Pasal 57 huruf (a) Kompilasi Hukum Islam di Indonesia Inpres Nomor 1 Tahun 1991.

e. Menimbang, bahwa alasan permohonan Pemohon untuk mengajukan Poligami adalah karena belum mempunyai keturunan.

f. Menimbang, bahwa di dalam permohonannya Pemohon menyatakan sudah lama menikah dan tidak mempunyai keturunan, maka Majelis Hakim menilai wajar bila Pemohon ingin menikah lagi untuk mendapatkan keturunan sebagai penyambung sejarah hidupnya, oleh karena itu alasan Pemohon sebagaimana diatur didalam Pasal 4 ayat (2) huruf (c) Undang-undang Nomor 1 Tahun 1974 tentang Perkawinan tidak terpenuhi, hal ini dikuatkan pula Pemohon dan Termohon selama perkawinan belum mempunyai anak.

g. Menimbang bahwa syarat formil dan syarat materiil terpenuhi dan Termohon didepan persidangan menyatakan bersedia dimadu oleh Pemohon sebagaimana diatur dalam Pasal 5 ayat (1) huruf (a) Undangundang Nomor 1 Tahun 1974 tentang Perkawinan jo Pasal 41 buruf (b) Peraturan Pemerintah Nomor 9 Tahun 1975 tentang Pedoman Pelaksanaan Undang-undang Nomor 1 Tahun 1974 tentang 
Perkawinan jo Pasal 58 ayat (1) huruf (a) dan (b) Kompilasi Hukum Islam di Indonesia Inpres Nomor 1 Tahun 1991, oleh karena itu dapat di pertimbangkan.

h. Menimbang, bahwa berdasarkan pernyataan Pemohon secara lisan dihadapan sidang maupun pernyataan secara tertulis serta dikuatkan pula oleh saksi-saksi diatas sumpahnya menyatakan sebagai suami mempunyai penghasilan yang cukup dipandang mampu menjamin istri-istri dan anak-anaknya sehingga telah terpenuhi Pasal 41 huruf (c) Peraturan Pemerintah Nomor 9 Tahun 1975 tentang Pedoman Pelaksanaan Undang-undang Nomor 1 Tahun 1974 tentang Perkawinan jo Pasal 58 ayat (1) huruf (b) Kompilasi Hukum Islam di Indonesia Inpres Nomor 1 Tahun 1991.

i. Menimbang, bahwa untuk menguatkan permohonannya Pemohon telah menyatakan secara lisan dihadapan sidang sanggup berlaku adil terhadap istri-istrinya dan secara tertulis telah menandatangani pernyataan untuk itu, maka telah memenuhi Pasal 41 huruf (d) Peraturan Pemerintah Nomor 9 Tahun 1975 tentang Pedoman Pelaksanaan Undang-undang Nomor 1 Tahun 1974 tentang Perkawinan jo Pasal 55 ayat (2) Kompilasi Hukum Islam di Indonesia Inpres Nomor 1 Tahun 1991.

j. Menimbang, bahwa dari unsur keperdataan sebagaimana bukti P 9 yaitu keterangan penghasilan dimana Pemohon mempunyai penghasilan setiap bulan Rp. 6.000.00o (enam juta rupiah) Majelis Hakim menilai Pemohon mampu untuk memenuhi kewajiban seorang suami sebagaimana diatur didalam Pasal 80 ayat (4) dan Pasal 82 ayat (1) Kompilasi Hukum Islam di Indonesia Inpres Nomor 1 Tahun 1991.

k. Menimbang, bahwa sisi ibadah nikah adalah melaksanakan sunnah, disamping itu memberikan perlindungan serta ketentraman batin terhadap wanita-wanita yang belum bersuami seperti halnya calon istri kedua Pemohon, sebagaiman pesan yang terdapat dalam Ar Rum ayat 21 yang berbunyi : 


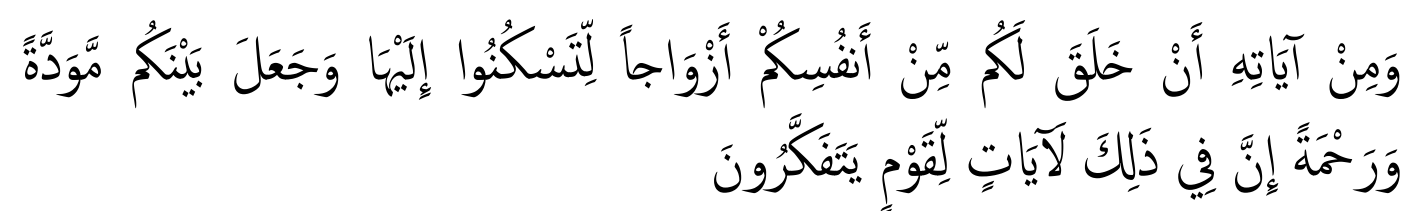

1. Menimbang, bahwa dari uraian diatas telah terpenuhi syarat-syarat formil maupun syarat-syarat materiil suatu perkawinan, serta Majelis Hakim memandang poligami yang dilakukan oleh Pemohon adalah semata-mata mementingkan nilai-nilai ubudiyah sehingga apa yang diharapkan oleh Pemohon adalah karunia dari Allah yang Maha memberi Karunia, sebagaiman pesan yang terdapat dalam surat An Nur ayat 32 yang berbunyi :

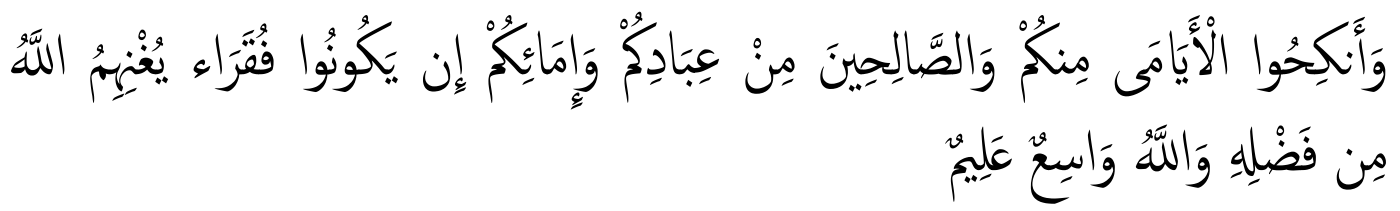

m. Menimbang, bahwa Majelis Hakim perlu mengetengahkan dalil dari surat An Nisa' ayat 3 yang berbunyi :

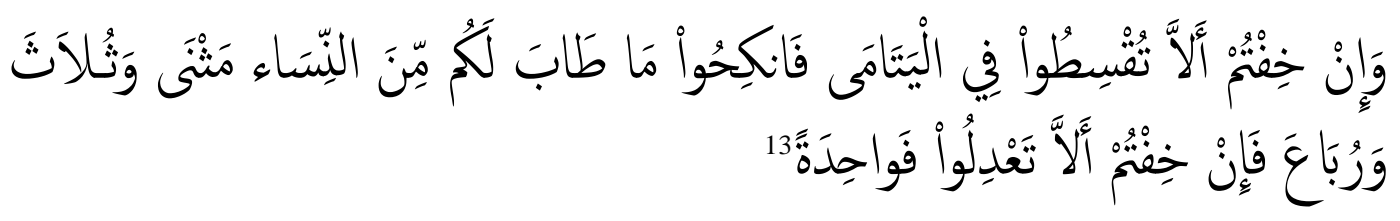

\section{E. Kesimpulan}

Pernikahan Poligami di KUA Playen pada tahun 2012 sampai dengan tahun 2015 sangat kecil dibandingkan total jumlah perkawinan yang dicatatkan di situ. Dari 0,20\% perkawinan, semuanya adalah pernikahan poligami kedua. Dasar Sosiologisnya pun masih mencatat kelangsungan keturunan sebagai prioritas dalam pelaksanaan nikah poligami di KUA tersebut. Karena itu, pertimbangan kemaslahatan menjadi pertimbangan yuridis yang dikedepankan dengan penguatan dasar hokum kebolehan poligami di Indonesia.

\section{Daftar Pustaka}

Al-Attar, Abdul Nasir Taufiq. Poligami di Tinjau dari Segi Agama, Sosial dan Perundang Undangan. Terj: Khotijah Nasution. Jakarta: Bulan bintang, 1976.

Abdurrahman. Karakteristik Hukum Islam dan Perkawinan. Jakarta: Raja Grafindo Persada, 1990.

${ }_{13}$ Salinan Putusan PA Mungkid Nomor 0410/Pdt.G/2015/PA.Mkd. 


\section{Pernikahan Poligami Di Wilayah Administrasi}

KUA Kecamatan Playen Tahun 2012-2015

Departemen Agama RI. Al Qur'an dan Terjemahannya. Semarang : CV. Toha Putra, 1995.

Nasution, Khoiruddin. "Perdebatan Seputar Status Poligami", Musawa, Jurnal Islam dan Gender Vol. I, No. 1, Maret 2002

Irawan, Andrie. "Harmonisasi Hukum Nasional dan Hukum Islam dalam Mencari Batasan Usia Minimal Menikah bagi Anak," Jurnal Hukum Respublica, Vol. 10, No. 2, h. 247-26o

Majalah Asy Syariah, Poligami Problem atau Solusi?, Edisi 85/ VIII / 1433 / 2012.

Ridwan, Muhammad Saleh "Poligami Dalam Perundang-Undangan Perkawinan di Indonesia", Al-Risalah : Volume 10 Nomor 2 Nopember 2010.

Al-Jahrani, Musfir Husain. Poligami dari Berbagai Persepsi. terj. Muh. Suten Ritonga. Jakarta: Gema Insani Press, 1996.

Kholis, Muhammad Nur."Konsep Kepala Keluarga Antara Laki-Laki Dan Perempuan Dalam Surat An Nisa (4) Ayat 34." Istinbath Jurnal Hukum Vol 12 No 2 (2015), h. 274-29o, http://e-journal. metrouniv.ac.id/index.php/istinbath/article/view/585

Soewadi, Dkk. Panduan Menuju Keluarga Sakinah. Yogyakarta : Bidang Urusan Agama Islam Kanwil Kementerian Agama Provinsi DIY, 2011.

Soemiyati. Hukum Perkawinan Islam dan Undang-Undang Perkawinan No.1 Tahun 1974. Yogyakarta: Liberti, 1999.

Tihami dan Sahrani, Sohari. Fikih Munakahat Kajian Fikih Nikah Lengkap, cet. 2, Jakarta: Rajawali Press, 2010

Undang-undang No 1 Tahun 1974 tentang Perkawinan

Direktur Urusan Agama Islam dan Pembinaan Syariah Direktorat Jenderal Bimbingan Masyarakat Islam Kementerian Agama Republik Indonesia, Himpunan Peraturan Perundang-Undangan Tentang Perkawinan, Jakarta: 2015. 
Asmorohadi 